\title{
Paleodrainage network reconstruction on Miroč Mt. (Eastern Serbia)
}

\author{
Aleksandar S. PETROVIĆ ${ }^{*}$, Jelena ĆALIĆ ${ }^{2}$, Vojkan GAJOVIĆ ${ }^{3}$ \\ ${ }^{1}$ Faculty of Geography, University of Belgrade, Belgrade, Serbia \\ ${ }^{2}$ Geographical Institute "Jovan Cvijić" of the Serbian Academy of Sciences and Arts, Belgrade, Serbia \\ ${ }^{3}$ GDi GISDATA, Belgrade, Serbia
}

Received 24 September 2016; Revised 9 October 2016; Accepted 14 November 2016

*Correspondence to: Aleksandar S. PETROVIĆ, e-mail: apetrovic@gef.bg.ac.rs

\section{ABSTRACT}

The paper represents a geomorphological study related to the transitional forms between fluvial and karstic process. Karst areas of eastern Serbia are distributed in a large number of relatively isolated segments, and therefore abound in contact karst features. In many cases, central parts of karst areas, away from the contacts, host a variety of relict and dry valleys. Morphological analysis of these valleys may reveal the remnants of paleodrainage networks and help to reconstruct the morphological evolution of the area. This is a case study of the karst of Miroč Mt. in north-eastern Serbia, where geomorphological analysis and relief visualization using the Geomorphological Information System enabled the detection of paleodrainage directions and patterns in the vicinity of the Danube Gorge. Three paleo-river systems were detected, the largest of which is that of the Suva Reka $\left(51 \mathrm{~km}^{2}\right)$.

KEYWORDS

karst morphology, paleodrainage networks, stream order, GIS, Serbia

\section{Introduction}

Carpatho-Balkan mountains of eastern Serbia have a relatively complex geological composition, consisting of the lithologies of almost all ages from the Proterozoic to the Quaternary. Several large orographical units, stretching from the Danube Gorges (Iron Gates) on the north, to the Balkan Mt. and further to the south-east, are composed predominantly of carbonate rocks of either Jurassic or Cretaceous age. These carbonate mountains are characterised by dry slopes and plateaus, dissected by deep gorges of allogenic streams. 
One of the most significant mountains of the eastern Serbian Carpathians is Miroč Mt. The aim of this paper is to analyze the elements of Miroc surface karst morphology in terms of detecting the extensive linear forms - relict valleys in karst. Most references attribute the origin of these valleys to the fluvial process, active prior to the onset of the karstic process. In certain cases, the linear morphologies are still visible on the mildly inclined karst surfaces, while in most other cases the suspected river network is totally disintegrated.

By the term "paleodrainage network reconstruction" we consider the detection of dry and relict valleys on karst, identification of possible thalwegs (e.g. Bočić et al., 2015) and interpretation of possible sequence of geomorphological evolution. Most references claim the fluvial origin of this kind of valleys (Warwick, 1964; Bočić, 2003; Košutnik, 2007; Povara and Conovici, 2013; Petrović, 2015), while some refer to tectonic origin (Gams, 1998).

In Serbian literature, fluvial interpretations of linear forms on Miroč karst are dominant (Cvijić, 1921; Milić, 1965; Zeremski, 1988). However, detailed morphological analysis of the dry and relict valleys was missing. This paper gives one of the possible interpretations of morphological evolution of Miroč karst plateau, with the main aim of determining the directions of the former drainage.

\section{Geological-geomorphological characteristics of the study area}

Mt. Miroč belongs to the northernmost part of the Carpathian Mts of eastern Serbia (Fig. 1). It stretches in N-S direction for about $25 \mathrm{~km}$, with maximal width of $8 \mathrm{~km}$ in $\mathrm{W}$-E direction. The highest point in relief is the Veliki Štrbac peak (768 m a.s.l.), while the lowest points are situated on the Danube banks (68 $\mathrm{m}$ a.s.l. on average). The largest part of the mountain surface lies between 400 and $500 \mathrm{~m}$ a.s.l. Karst relief covers $143.5 \mathrm{~km} 2$ and limestones are predominantly of the Upper Jurassic age.

Tectonically, Mt. Miroč is an autochtonous unit represented by the Miroč anticline. The anticline axis strikes approximately in N-S direction (Anđelković and Nikolić, 1980).

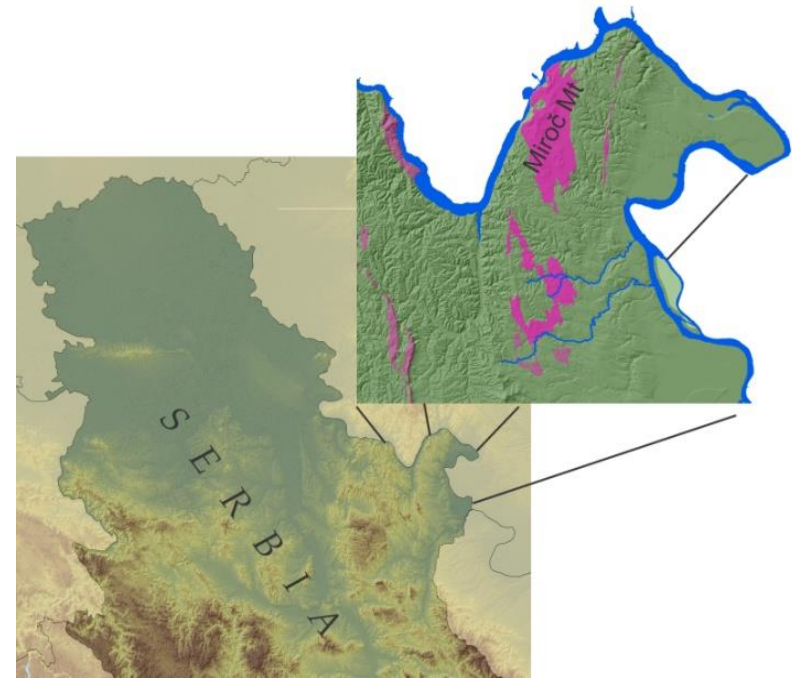

Figure 1 Location of the research area

On the anticline limbs, on the eastern and western side, there are remnants of the Gethic nappe that formerly covered the area. The anticline hinge is in one segment eroded to the Middle Jurassic marls, which are the oldest lithology on the plateau, representing a tectonic window (Anđelković and Nikolić, 1980). Central parts of Miroč consist of the Tithonian reef limestones (J33) (Fig. 2), surrounded by marly Cretaceous limestones and flysch (Bogdanović and Rakić, 1980). The core of the Miroč anticline consists of the Precambrian crystalline schists (Anđelković and Nikolić, 1980).

Tectonic setting of Miroč, with the dominant anticlinal form, led to the development of the systems of vertical ruptures in limestones, striking predominantly $\mathrm{N}-\mathrm{S}$ along the anticline axis. Apart from those, structural-tectonic mapping carried out within the series of speleological explorations of the area revealed the ruptures striking NE-SW as well (Zlokolica-Mandić et al., 1996; Mandić et al., 1997).

In the surface morphology of Mt. Miroč, the forms of karstic and fluvio-karstic process clearly dominate: dolines, some small uvalas, and blind valleys. The karstic plateau Miroč - Ciucarul Mare (in Romania), which was once a continuous morphological unit, today is divided by the deep Danube gorge. Thus, the western rims of the Miroč karst plateau are represented by the high, steep escarpments towards the Danube (Fig. 3). 


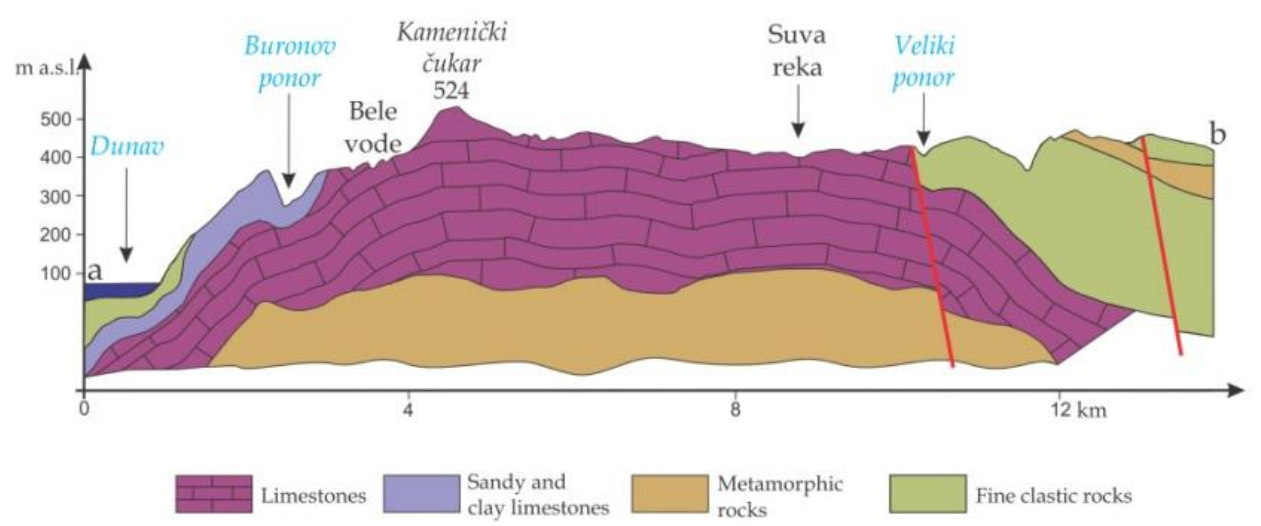

Figure 2 Structural-tectonic profile of Miroč Mt. (profile a-b on Fig. 5)

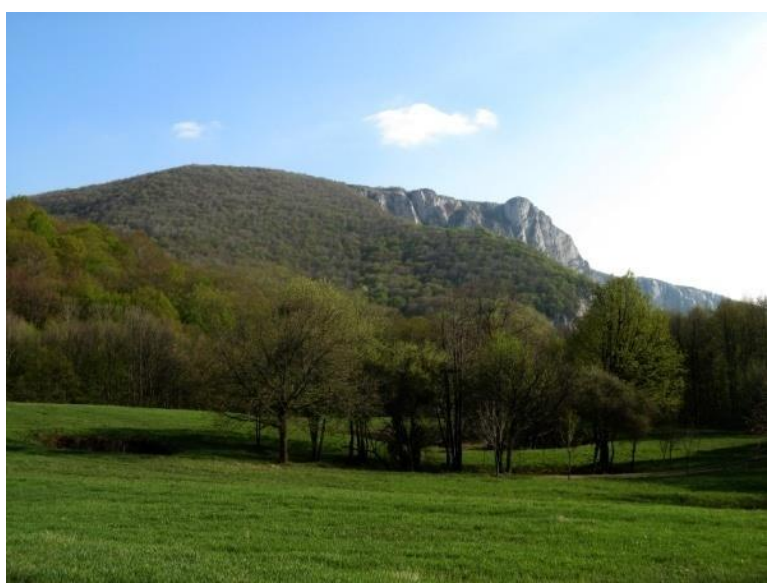

Figure 3 Steep escarpments of the Veliki Štrbac peak above the Mali Kazan gorge

Dolines are the most usual karst form on Miroč Mt. In a detailed morphological study, Telbisz et al. (2007) detected 3164 dolines, with an average density of $24.9 \mathrm{~km}^{2}$. Distribution analysis shows that the dolines are grouped in several belts of N-S direction (Fig. 4), and are present on the surfaces with the inclinations of up to $12^{\circ}$ (Telbisz et al., 2007).

\section{Methods}

Reconstruction of the paleodrainage network on Miroč Mt. was done on the basis of fieldwork, geomorphological mapping and GIS analysis. The series of previous morphological studies in this area (to mention just a few - Zeremski, 1988; Mandić et al., 1997; Djurović (ed.), 1997; Ljubojević, 2001;
Telbisz et al., 2007; Mari et al., 2007; Ćalić (Ed.), 2015; Petrović, 2015) have covered the research of surface and underground forms of the Miroč karst. The results have depicted the mutual relations both between the surface karstic and non-karstic morphology, and the surface and underground karst. The fieldwork was the introduction to the geomorphological mapping of the Miroč karst plateau and the development of the Geomorphological Information System - GmIS (Petrović, 2015). Geomorphological mapping was carried out according to the standards of the Detailed geomorphological map of SFR Yugoslavia at the scale 1:100.000 (Gams et al., 1985), and the symbols and colours in this paper follow these standards as well.

The basis for the GmIS was the digital terrain model (DTM), set up by digitizing of contours of 10 $\mathrm{m}$ vertical resolution and using interpolation techniques. For the development of the DTM, as well as for the complete GmIS, the ESRI package for geospatial data processing ArcMap was used.

The results of the mentioned studies and analyses (particularly the doline distribution) have helped in determination of particular parts of the drainage network in three types of valleys: active, dry and relict (cf. Bočić et al., 2010; 2015; Petrović, 2015). Active valleys are those which host permanent or seasonal waterflows, the latter being much more frequent on Miroč. Dry valleys are without any water streams at the bottom, but they have a valley bottom of continuous inclination towards the former "mouth" into the main watercourse (Petrović, 2015). This type of valleys is 
the least represented on Miroč and therefore are not visible in the figures within this paper, due to the scale. Relict valleys do not have a continuous inclination of the valley bottom, but the thalwegs host series of dolines, roughly indicating the fluvial pattern (Petrović, 2015; Bočić et al., 2015). This is the dominant type of valleys on Miroč.

Reconstructed drainage networks on Miroč (and the valleys within them) were grouped in ordersand shown on the map (Fig. 5) according to the Strahler method (Strahler, 1957), taking into account the frequency distribution of the length of the valley segments and relation of stream length to stream order.

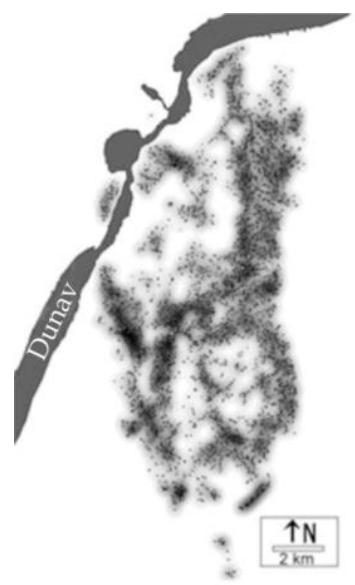

Figure 4 Doline density on Miroč Mt. (Telbisz et al., 2007)

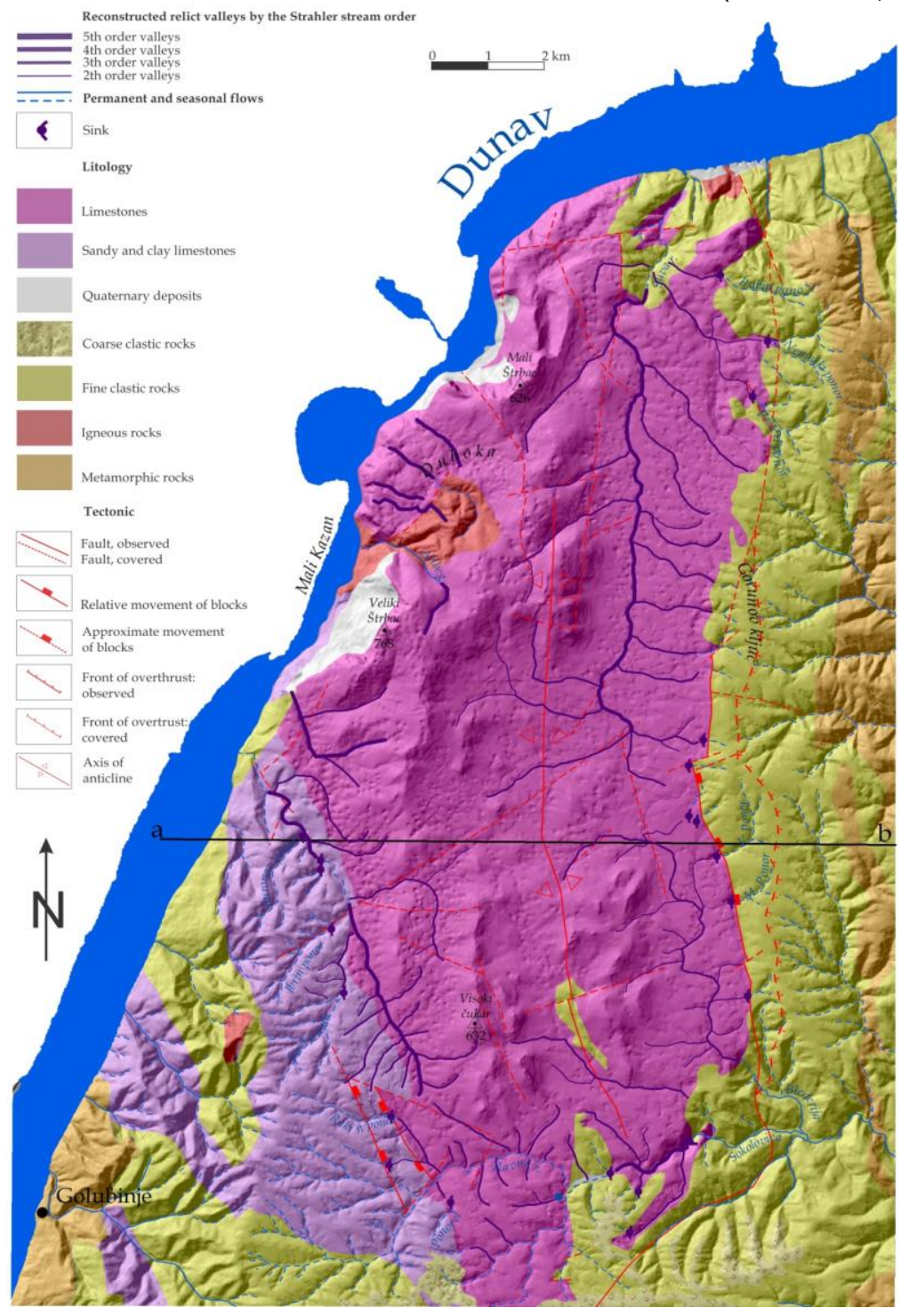

Figure 5 Map of Miroč Mt. with paleodrainage network 


\section{Results}

Karstic plateau of Miroč is surrounded on three sides by impermeable rocks, so it can be said that its perimeter is characterised by contact karst. To the east and west from the karstic plateau, the area is somewhat higher. Therefore the short streams (11,5km) descend towards the limestones (Fig. 5). Considering the small quantity of water in temporary streams, they by rule sink on the contacts or immediately downstream from the contacts. Two long lines of blind valleys (western and eastern) were formed in this way (Petrović, 2015).

The eastern belt of blind valleys starts close to the Veliki Beljan village on south-eastern Miroč (Veliki Ponor and Mali Ponor), finishing on the north with Babin Ponor (Fig. 5). Downstream of these ponors, the relief most usually shows karstified valleys belonging to paleodrainage networks of Cvetanovac (on the south) and Suva Reka (on the north) (Fig. 6). These valleys with dolines along their bottoms are hanging $15-40 \mathrm{~m}$ above the final parts of blind valleys. Due to a considerable degree of karstification, they do not have the continuous inclination of the valley bottom, so they belong to the group of relict valleys. The direction of the blind valleys and their downstream parts (relict valleys) is determined by the existence of the "tectonic depression" on the eastern limb of the Miroc anticline (Zeremski, 1988). Structural-tectonic impact is responsible also for the asymmetric form of certain drainage areas, especially in the case of Suva Reka (Fig. 6). For that reason, Suva Reka had much more right tributaries than left tributaries (Fig. 5). It is the valley of the relict type as well, $12.5 \mathrm{~km}$ long, ending $260 \mathrm{~m}$ above the Danube. Suva Reka is developed along the mentioned tectonic depression on the plateau. The western line of ponors and blind valleys starts with Ponorel on the south and ends with Buronov Ponor on the north (Ljubojević, 2001).

As opposed to the eastern rim of the Miroč karst, characterised by the contact of limestones and fine clastic rocks (Fig. 6), the western contact lies in the zone where the Upper Jurassic limestones are present next to the Lower Cretaceous marly and clayey limestones in normal sedimentary superposition (Fig. 5).

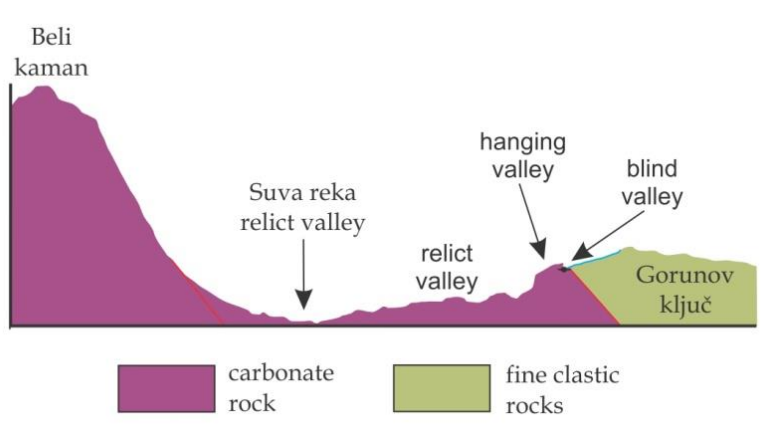

Figure 6 Cross section of the Suva Reka relict valley

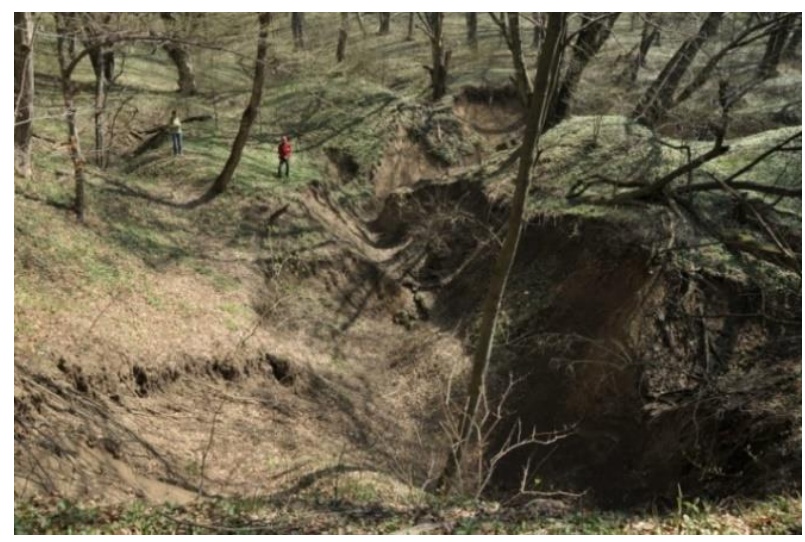

Figure 7 Cvetanovac Ponor (photo: D. Smiljković)

Next to this contact, the dry/relict valley of Bele Vode and its drainage network are formed. The similarity between the Bele Vode drainage pattern and Suva Reka drainage pattern lies in the direction of the main valley and asymmetric shape of the drainage area. There are several differences as well. Apart from being karstified, the valley of Bele vode is more conspicuous in relief than the valley of the Suva Reka. In the central part, there is a weak watercourse, so the valley is not completely relict. The valley of the Bele Vode is $6.6 \mathrm{~km}$ long, ending about $100 \mathrm{~m}$ above the Danube. The valleys of the former left tributaries of the Bele Vode end blindly 10-30 $\mathrm{m}$ lower than the main valley bottom. They are slightly shorter $(2-3 \mathrm{~km})$ than the blind valleys in the paleodrainage network of the Suva Reka.

In the southern part of the Miroč karst plateau, there is the third paleodrainage network Cretanovac (Ravna Reka). It consists of active, dry, relict and blind valleys. The fact that two toponymes exist for this drainage area points to the different 
characteristics of particular parts of the valley. The upstream segment of the Ravna Reka lies in impermeable rocks. Reaching the limestone part of the basin, the Ravna Reka sinks into the fissures on the valley bottom. Only during the floods, the flow reaches the downstream parts of Cvetanovac (Milić, 1965). This part of the valley is hanging $15 \mathrm{~m}$ higher than Cvetanovac. All the tributaries in the karstic part of the area are dry, with dolines along the bottoms. Cvetanovac is seasonally hydrologically active, fed by the karst spring of Frusenis Potok. Alluvial sediments, into which Cvetanovac waters are sinking, cover the contact between impermeable lithologies and limestones (Fig. 7).

Downstream from the ponor, there is a relict valley of the main river, hanging on both sides, with the relict valleys of their paleo-tributaries. Cvetanovac waters emerge from the outflow cave Sokolovica (Zeremski, 1988) and feed into the Blederija River. The valley of the former northern tributary of Cvetanovac, which was draining the south-eastern part of the Miroč tectonic depression, remained hanging high above the present spring of Blederija (to see Fig. 5).

\section{Discussion}

The initial relief of Miroč Mt. was a central plain of a former marine strait that existed during the maximum of the Pontian transgression (Milić, 1965). The strait was subsequently used by the Paleo-Danube for the development of its epigenetic valley (the Kazan gorge). At that time, Bele Vode and Suva Reka were the right tributaries of the Paleo-Danube (Cvijić, 1921), which was subsequently feeding into the Dacian Sea. Ravna Reka (Cvetanovac) also flew to the Dacian Sea, to the south-east of Miroč.

All three rivers formed their drainage areas in impermeable rocks that were covering the limestones. Having in mind the lengths of the tributaries, the sizes of the drainage areas (max. 51 $\mathrm{km}^{2}$, Suva Reka) and the fact that the main valleys belong to the 4th order in Strahler's classification (Strahler, 1957) (Fig. 8), we can conclude that these flows did not have considerable discharges.

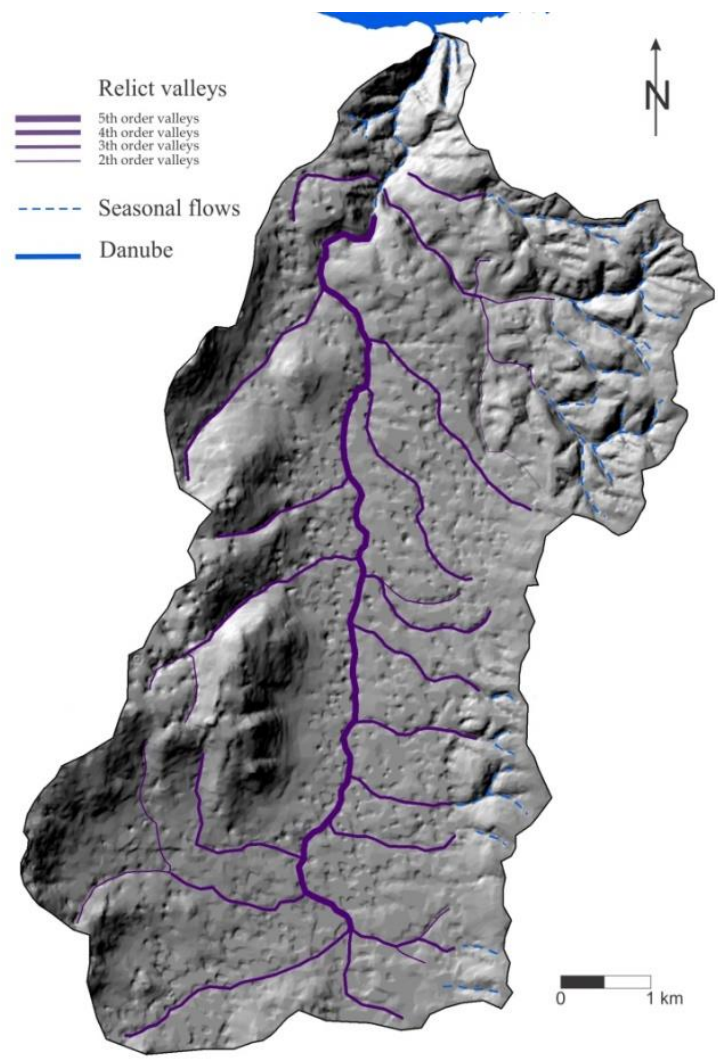

Figure 8 Paleodrainage network of the Suva Reka river reconstruction on central Miroč Mt.

The valleys of the Suva Reka and Bele Vode stretch in the N-S direction. Structural-tectonic influence of the Miroč anticline on the drainage pattern is evident. The further evolution of the drainage network caused the impermeable lithologies to be washed away. This process led to the development of fluvio-karstic levelled surfaces below the peak of Veliki Štrbac (Zeremski, 1988). After the recession of the Dacian Sea towards the east, faster incision of the Danube took place. This was the most important factor of the karstification of Miroč karst plateau, apart from the mentioned intense fissured porosity ("la fracturation particulierment intense"; Ambert and Niccod, 1981), small discharge of the streams and the existence of extensive fluvio-karstic surfaces (Petrović, 2015). NEdipping limestones enabled the groundwaters to drain towards the Danube, using the existing systems of fissures. Miroč limestones are deeply karstified, which is proven by the existence of strong karst springs (Pena, Pešter, Hajdučko Vrelo, Bele Vode), as well as by the depth and extent of major 
caves, like Rakin Ponor, Nemački Ponor, Buronov Ponor (Zlokolica-Mandić at al., 1996). Their depths may exceed 200 m, with max.-285 m depth in Rakin Ponor (Ćalić (ed.), 2015).

With gradual sinking of surface waters on Miroč, the fluvio-karstic phase finishes, giving the dominance to the karstic phase in relief formation. Due to intensive karstification, the bottoms of the valleys of Bele Vode and Suva Reka, together with their tributaries, turn to dry valleys and subsequently to relict valleys with dolines at their bottoms. Deep dolines completely changed the previously present relief forms, so a number of relict forms are difficult to distinguish. However, higher density of dolines (Fig. 4) point to the paleodrainage areas of Bele Vode, Suva Reka and Ravna Reka (Cvetanovac), within which one can reconstruct the former valleys of the main rivers and their major tributaries.

\section{Conclusions}

Former studies of karst relief on Miroč Mt. did not completely reconstruct the drainage pattern on the Miroč karst plateau. The reason was probably the fact that the relict valleys in karst were difficult to distinguish, due to the long-term impact of karstic process on the former fluvial relief. Usage of the modern geospatial analysis tools, as well as the formation of the GmIS, enabled the more precise reconstruction of paleo-drainage areas and paleodrainage networks on Miroč Mt.

Suva Reka, Bele Vode and Ravna Reka (Cvetanovac) were short water courses with relatively small drainage areas (max. $51 \mathrm{~km} 2$ ). The first two were feeding into the Paleo-Danube, and Ravna Reka directly into the Dacian Sea. Development of the paleodrainage networks of these rivers turned from fluvial to fluvio-karstic phase after the erosion washed away the impermeable surface layers. Fast withdrawal of the Dacian Sea and, accordingly, incision of the Kazan Gorge of the Danube intensified the transition from fluvio-karstic to the karstic phase. Active streams disappear from the karst plateau of Miroč, while their valleys become dry. With the long-term impact of the karst process, deep dolines develop along the thalwegs of the dry valleys, turning them into the relict valleys. Only the allogenic river of Ravna Reka remains active at some segments. Short streams from the impermeable parts of the former drainage areas sink on the contact with limestones or immediately downstream from the contact. These streams form two N-S oriented belts of blind valleys - eastern and western. Relict valleys of the Bele Vode, Suva Reka and Ravna Reka (Cvetanovac) remain in hanging positions high above the Danube and Blederija.

\section{References}

Ambert P, Nicod J. 1981. Sur quelques karsts de Serbie, au voisinage du Danube. Leurs rapports avec l'évolution du bassin pannonien. Revue Géographique de l'Est 21(4): 235-249.

Andjelković M, Nkolić P. 1980. Tektonika Karpatobalkanida Jugoslavije. Univerzitet u Beogradu 20: 1248.

Bocić N. 2003. Relation between karst and fluviokarst relief on the Slunj plateau (Croatia). Acta Carsologica 32: 137-146.

Bocić N, Pahernik M, Bognar A. 2010. Geomorfološke značajke Slunjske zaravni (Geomorphological characteristics of the Slunj karst plateau). Hrvatski Geografski Glasnik 72: 5-26.

Bocić N, Pahernik M, Mihevc A. 2015. Geomorphological significance of the palaeodrainage network on a karst plateau: The Una-Korana plateau, Dinaric karst, Croatia. Geomorphology 247: 55-65.

Bogdanović P, Rakić M. 1980. Tumač za listove Donji Milanovac, Oršava, Baja de Arama i Turnu Severin. Savezni geološki zavod, Beograd.

Ćalić J. (ed.) 2015. Caves in the Djerdap National Park. Public Enterprise Djerdap National Park, Donji Milanovac. Beograd, $200 \mathrm{p}$.

Cvijić J. 1921. Djerdapske terase. Glas Srpske kraljevske akademije vol. $\mathrm{CI}(43)$ : 1-31.

Djurovic P. (ed.) 1998. Speleological atlas of Serbia. Serbian Academy of Science and Arts, Geographical Institute"Jovan Cvijić", special edition 52, p. 1-290.

Gams I, Zeremski M, Marković M, Lisenko S, Bognar A. 1985. Uputstvo za izradu detaljne geomorfološke karte SFRJ u razmeru 1:100.000. Odbor za geodinamiku Srpske akademije nauka i umetnosti, Beograd, 160 str.

Gams I. 1998. Geomorphogenetics of the Classical Karst Kras. Acta carsologica 17(2): 181-198. 
Kosutnik J. 2007. Questions of dry valleys in karst: case study of Mali dol, Kras, (Slovenia). Acta Carsologica 36: 425-431.

Ljubojević V. 2001. Caves of Mt. Miroč (Danube gorge, Eastern Serbia). 13th International Congress of Speleology, Brasilia, pp. 493-498.

Mandić M, Pavlović R, Lozajic A, Ljubojević V. 1997. Speleological characteristics of the Miroc Mountain and their relation to the tectonic framework. Geology of Djerdap Area - Proceedings, International symposium Geology in the Danube gorges, Belgrade Bucharest: 117-120.

Mari L, Telbisz T, Ćalić J. 2007. A Kazan-Szorosok deli oldalan magasodo Miroč - hegyseg karsztos formakincse. Karsztfejlodes XII: 153-169.

Milić Č. (1965). Morfologija kraške oaze Miroča. Zbornik radova Geografskog instituta "Jovan Cvijić" SANU 20: 15-56.

Petrović A. 2015. Influence of modifiers on the polymorphism of valleys in karst of the Serbian Carpatho-Balkanides. PhD thesis, University of Belgrade, Geography faculty, Beograd, p. 1-264.
Povară I, Conovici M. 2013. Tectono-karst depressions in the central western area of the Mehedinţi mountains (SW Romania). Travaux de I'Institut de Speologie Emile Racovitza 52(1): 37-49.

Strahler AN. 1957. Quantitative analysis of watershed geomorphology. Transactions American Geophysical Union 38: 913-920.

Telbisz T, Mari L, Ćalić J. 2007. Morfometrijska analiza vrtača na Miroču upotrebom GIS-a. Bulletin of the Serbian Geographical Society 87(2): 21-30.

Warwick TG. 1964. Dry valleys of the Southern Pennines, England. Erdkunde 18: 116-123.

Zeremski M. 1988. Geomorfološka karta kraške oaze Miroča. Zbornik radova Odbora za kras i speleologiju SANU III: 7-21 Beograd.

Zlokolica-Mandić M, Mandić M, Ljubojević V. 1996. Some Significant Caves at the Western Rim of the Miroč Karst (Yugoslavia). Academia Romana, Institutul de Speleologie "Emil Rocovita", Theoretical and Applied Karstology 9. 